\title{
Configuring Land Rights Registration in the Agrarian Legal System (Comparative Study of Government Regulation Number 10 of 1961 with Government Regulation Number 24 of 1997)
}

\author{
Sri Sunarni", Zainal Asikin **, Widodo Dwi Putro ${ }^{* *}$ \\ * Student of Magister Law Study Program, Postgraduate Program, Mataram University, Indonesia \\ ** Lecture of Law Faculty Mataram University, Indonesia
}

\begin{abstract}
Normative research concerning Configuring the Replacement of Regulations on the Registration of Land Rights by addressing the issue of ideology and Raison de Etre's rule of law gave the conclusion, that the Registration of Mastering Rights by the State should respect and recognize individual rights to land.

From the analysis and discussion that discusses, conclusions can be drawn, that is the Right to Mastery over the Land held by the Government agrees if it has the power to connect the economic sector. More details can be found: Registration of land rights cannot be agreed with political policies on land use. In the implementation of PP 10 of 1961 the government seized people's land rights, then redistributed the people who needed it as agricultural land (in addition, this program of land redistribution was communicated to the government as an asset with public reasons; it found different political attitudes when implement PP 24 of 1997, namely: by regulating the fundamentals of a new government-finance and vice versa with the Pancasila Philosophy as a principle of Efficiency-Justice Actually it was implemented at the beginning of Repelita I by enacting Law No. 1 of 1967 (Foreign Investment) A comparable increase is needed with the people's prosperity which is relatively difficult to achieve (PP 10 of 1961) which seeks to increase government original income (PAD).
\end{abstract}

Keywords: configuration, land rights, agrarian legal system

\section{Introduction}

Research on changes to the regulation of registration of land rights from Government Regulation Number 10 of 1961 into Government Regulation Number 24 of 1997 concerning Land Registration is very important, because the change is only understood as a change in technical legislation; whereas the two Government Regulations (PP) were born during different legal ideological and political configurations: PP 10 of 1961 concerning Land Registration was born at the time of the start of the land reform program in the Old Order, while PP 24 of 1997 concerning Land Registration was issued during the crisis period economy, Indonesia's dependence on foreigners, and towards the fall of the New Order regime.

If people only read scripturalistic regulations (black-letter law), they will certainly fail to understand raison d'etre, the reason for the existence of the regulation. For example, Law Number 5 of 1960 concerning Basic Agrarian Regulations (hereinafter abbreviated as UUPA), in Article 19 instructs the registration of land in order to guarantee legal certainty. The purpose of the Registration in Article 19 paragraph 2 of the BAL is stated as follows:

1. Measurement, mapping and bookkeeping of land.

2. Registration of land rights and the transfer of these rights

3. Provision of documents of proof of rights that apply as a strong evidence tool.

Reading Article 19 of the BAL is scripturalistically, reducing the meaning of the article to be merely administrative-technical registration, namely regulating measurements, mapping, land records to the provision of proof of rights documents that apply as a strong evidentiary tool. Whereas the meaning behind land registration cannot be separated from the spirit and purpose of the LoGA, namely, laying the legal 
foundation regk,,arding monumental and revolutionary land redistribution, one of which is reforming the imbalanced land ownership structure to become more socially just. The LoGA includes regulating land tenure restrictions, equal opportunities for every citizen to obtain land rights, recognition of customary law, and foreign nationals without ownership rights.

Article 19 of the BAL was then elaborated and further regulated by Government Regulation Number 10 of 1961 concerning Land Registration. The task of land registration, not only includes measuring, mapping and registering one's rights, but also for the implementation of conversion of land rights and land information, in order to facilitate the implementation of land reform. The task of the Land Office in the Basic Agrarian Law (UUPA) also includes maintaining that the principle of Nationality of land rights is carried out consequently. Likewise, the implementation of Indonesian land reforms must be strictly implemented, such as the absentee ban, the prohibition of extensive land ownership (ban lantifundia), and the prohibition on the transfer of rights to agricultural land without permission. After land registration, the next stage is the determination of land categorized as "more land" and its distribution to landless farmers based on Law 56 / PRP / 1960.

The government has begun implementing landeform programs since September 24, 1961 by establishing agrarian committees tasked with registering land ownership whose area exceeds the maximum limit allowed by the law and absentee lands whose owners are absent. It is recorded that there are around twenty-seven thousand owners of paddy fields whose land area exceeds the maximum limit with a total land area of more than one million hectares which is ready to be redistributed to landless farmers around it.

The purpose of land registration at that time was to know and provide legal certainty regarding land ownership and control. Excessive land or exceeding the maximum limit of ownership then becomes the object of land reforms distributed to landless farmers. This means that PP Number 10 of 1961 concerning Land Registration is the "life" of the work of agrarian institutions in the field of land registration at that time in order to facilitate the land reform program.

After the Old Order fell and was replaced by the New Order regime, the land reform program was "stopped". After 1965, the Department of Agrarian Affairs was lowered to the level of the Directorate General within the Ministry of Home Affairs and the division that handled land registration was called the Directorate of Land Registration. Since then land registration is no longer a part of land reform but rather an administrative problem of registration.

During the New Order, the government policy changed, namely, directly intervening in the policies on land which originally had its vision for reforming unequal land ownership through redistribution of land to landholders (land reform) and then turned into land for development and investment purposes. Uniquely, the LoGA which was the basis for implementing the land reform was not replaced, legally the LoGA remained in effect until now but was "put to sleep" (statutory dormancy). Likewise, PP 10 of 1961 was not immediately revoked or amended, but policies and implementation of land registration were oriented to the certainty of land rights for development and investment purposes.

Based on the previous description, the following problems can be formulated:

1. Fundamental differences between PP No. 10 of 1961 with PP. No. 24 of 1997 concerning land registration;

2. With regard to calling PP 10 of 1961 to PP 24 of 1997: a). the legal ideology behind the exposition of changes in government regulations; b). the reason for the existence of ("raison d'etre") PP 24 of 1997 so as to replace PP 10 of 1961;

\section{Method}

The Approach Method that I use in this study is:

a. Statute Approach

According to Peter Mahmud Marzuki, "Approach to the Law, namely:

The statute approach is carried out by examining all laws and regulations relating to the legal issues being addressed. For researchers for practical activities, this Law Approach will open opportunities for researchers to study whether there is consistency and conformity between an Act and other Laws or between Laws with the Basic Laws or between regulations and laws. ${ }^{1}$

b. Conseptual Approach

According to Peter Mahmud Marzuki, "The conceptual approach, namely:

${ }^{1}$ Peter Mahmud Marzuki, Penelitian Hukum, 2nd edition of the first print. Kencana Prenada Media Group, Jakarta, 2006 , p. 93 
The conceptual approach moves from the views and doctrines that develop in law. By studying the views and doctrines in law, researchers will find ideas that give birth to legal notions, legal concepts, and legal principles that are relevant to the issues at hand.

c. Socio Legal

According to Mukti Fajar ND and Yulianto Achmad in Salim HS and Erliana Septi Nurbani the legal sociology approach, namely:

The legal sociology approach is an approach that analyzes how reactions and interactions occur when the norm system works in society. Besides that, it is also known as the sociological approach to law. This approach is constructed as something that is the behavior of a steady, institutionalized and socially legitimate society.

\section{Result and Discussion}

\subsection{Orientasi Ciritical Legal Studies}

Registration of land rights basically addresses the causal relationship between politics and law. The idealists who are more standing at the corner of Das Sollen say that the law must be a commander who is able to control and engineer the development of society, including his political life. Authors like the Roscue Pound have long been talking about how law is utilized as a social engineering tool. The law is put in place as a determinant of community travel, because with that the function of law to ensure order and protect public order will be relevant. But the Critical Legal Studies, the law is not value-free, in it is full of economic and political interests, even inevitably becomes a dependent variable on the circumstances outside, especially the influence of political penetration.

In fact, law was born from a reflection of the political configuration behind it. In other words, the sentences contained in the rule of law are nothing but the crystallization of the contestation of competing politicaleconomic interests. Ciritcal legal studies see the relationship between the political subsystem and the legal subsystem; political-economic interests have greater energy and concentration so that the law tends to be a reflection of these interests. ${ }^{2}$

The political influence on the law can apply to law enforcement and the characteristics of the products and the manufacturing process.

According to CLS, it is impossible to separate politics from law based on objectivity and legal neutrality arguments. CLS wants to put forward a legal analysis that is not only based on doctrinal aspects or mere formalistic approaches, but also considers factors outside the legal doctrine such as the influences of socialpolitical and economic factors in the process of forming the law.

Before carrying out a legal analysis it is necessary to have an adequate understanding of the content and doctrinal aspects of the law or what is called "internal relations", how to fill the legal norms. After that, it is only related to the reality of social, political and economic relations or what is called "external relation". Because there are differences in the analysis between the material and the internal structure of legal thinking on the one hand, and the variables outside of it that are likely to influence them are aspects of social, economic and political life on the other side. When connecting between aspects of "internal relations" in terms of "external relations". That's when the eclectic approach is used, especially to understand the reality of social, political and economic relations, as Kennedy believes; "We need to understand far more than we do about the content and the internal structure of legal thought before we can link it to any convincing way to other aspects of social. Political or economic life."3

In short, the theory of CLS wants to understand and criticize the political significance behind the legal doctrines which will at the same time reveal the veil of "hidden political intentions" behind the legal exposition. This CLS approach helps us to understand the relationship between legal doctrine and the context of the economic-political interests behind these legal norms.

\subsection{Platform for Registration of Land Rights}

For a country like Indonesia, the land registration program is basically an embodiment:

\footnotetext{
${ }^{2}$ Roberto Mangabeira Unger, Law in Modern Society, (Free Press, New York, 1976) hlm. 180.
} 
a) Sovereignty in the Territory is the main element in establishing the State. This is very important and becomes an existential study. Something can be said by the state if it has people, territory, sovereign government and the ability to establish relations with other countries.

That means, the territory of the State's sovereignty is mentioned as the second requirement following the people showing that the territory which is still the main requirement in the formation of a country. Because above that region, a country with a sovereign government will be held later.

b) Government power, dominating State and people allowed to own land based on value means that land is a gift from God, meaning land controlled or owned by someone also legal entity is a gift of God, therefore the meaning of land is God's creation, mandated, entrusted, given to humans to be used as provision of devotion to Him. So, it is a sacred treasure, not to be lowered in value such as valuing land as if a commodity can be traded or traded, abandoned, or not increased its usefulness;

This meaning contains normative values. The gifted land of the Creator that must be utilized in the framework of a trustworthy reciprocal relationship - between the Creator and his people, as well as between individuals and other parties. The main goal is to achieve the greatest prosperity and prosperity.

c) Embodiment of People's Prosperity; Constitutional legal relations in the form of the State's obligation to prosper the people because they are given the right or authority to manage land and natural resources found in Article 33 Paragraph (3) of the 1945 Constitution determine: people's prosperity. "

Indeed, the basic provisions involve two things, namely: the authority of the State (government) in the form of controlling various natural resources as long as the authority is within the framework of achieving the goal of prospering the lives of the people. Or in other words the Government manages natural resources in order to foster, develop and protect the lives of many people. The purpose of the prosperity of the nation is accompanied by a measure of the lives of many people, which means that various policies implemented by the government to realize the prosperity of the people must pay attention to the lives of many people. The government is permitted to control natural resources if it is related to natural resources. Here there is a government monopoly on certain businesses, such as relating to nine basic commodities.

It should be noted from this description, that the Land Reform Program was motivated by the ideological foundation of the nation which did not favor individualistic ideology. Land owned by landlords in the decade of the nineteen-five was taken by the State and returned to the community of farmers who needed it; the problem of ideology in relation to registration of land rights together with the enactment of laws and regulations concerning land reform and absentee provisions.

Excessive land tenure that took place before Indonesian independence, and even two decades after independence required restructuring of individual land ownership and control.

A case of land reform was found in the Mataram District Court, on February 5, 1964, Number: 474/1963 / PN / Pdt - which applies to descendants of landlords from Karang Bayan, Lingsar District (formerly Kearmatan Narmada), West Lombok District, who named I Gst Bagus Tjemoh (died 1922) whom he handed over to I Gst Bagus Oka Parta (died February 12,1926) and since then held and in the possession of a daughter named: I Gst Ayu Djelantik Bini as long as the girl made a request to Raad Kerta Tjakranegara on August 8, 1926, which application at that time had been strengthened or gotten goedkeuring from the voorzitter Raad Karta, which letter they named Testament, whose subject matter was to make the inheritance lands an invulnerable treasure, now the situation is this comparable list, forever may be broken up or divided up by the heirs until later in the day, and to one member of the expert the inheritance is given the right to control the inheritance and who gets the assignment is required to change its original name, use and name myself I Gusti Bagus Djelantik.

That was first appointed by I Gusti Bagus Rai, then (finally) was determined by Defendant I (I Gusti Bagus Djelantik, Leter) as the controlling heirloom until now it was held by him after mixed with molok pribadi from the late I Gusti Bagus Oke Parta, I Gusti Bagus Rai, and I Gusti Bagus Djelantik, Bini.

Disputes that occurred shortly before the legislative regulation Number 5 of 1950, in conjunction with Law Number 56 / Prp / 1960, and Government Regulation Number 224 of 1961. The Plaintiffs and Defendants who were a family with and brothers, agreed and made peace with the division of land object landform with consideration of the judge, as follows: 
Considering that Defendant I also acknowledged, that he had related his duties as head of the family, had reported the lands of Tjidra, in one list of "Reports on Ownership and Control of agricultural land in accordance with Article 3 of Perpu Number 56 of 1960", reported by him in room 5 "Land Owned ", while in room 6," Land Controlled "is left blank. So this mistake is caused when the Defendant I believes in the instructions of the other person, and has not been able to understand well the result of the difference in space 5 with space 6 of the example list.

Considering, given the enactment of Law Number 5 Year 1950 Landforms and Law Number 56 Prp Year 1960, the land that became the case has been affected by the implementing regulations on the Basic Agrarian Law. So to be able to know with certainty how now the status (status) of the Tjidra lands should be heard by the officials concerned as witnesses in order to resolve this dispute;

Considering whereas from the Panitya Landreform West Lombok Level II for this present Mamiq Muhammad BP II Level II West Lombok, deputy chairman Panitya Landrefom for the oath explained: "that the land over this case by Panitya has been taken a decision and has determined Defendant I ownership only rice fields covering an area of 11,245 ha, according to Chairman Panitya's letter dated February 1, 1963, Number: 1 / PL / 1963;

While the rest of the land, due to the implementation of Government Regulation Number 224/1961, since September 24, 1961 is land directly controlled by the State, to be distributed to those in need (redistributed), even that has been done partially. It was also explained the basics of Panitya taking a decision that considered the lands of Tjidra privately owned by Defendant I (I Gusti Djelantik Leter) based on his own report, then the research team had examined the names in Pipil and mastery of the results, always by Defendant I own. Even then, after he was presented with a list of ownership, he filled the land where he wanted it to remain and also registered the lands which he handed over to the State. During that period there was no hearing or advance that these lands were the rights of many people or undivided inheritance, and the witness stated that therefore the remaining lands were controlled by the State;

Considering that it was heard on the oath of Purnama Susila, the Head of the Lombok Level I Agrarian Office, who explained that it was similar to Mamiq Muhammad, especially in terms of the decision taken by Panitya siding;

Considering Then Mardanus the District Head of Narmada was heard in an oath, explaining, did not interfere with the detention of the rice fields of the Tjidra rice fields, because the tenants were directly related to Panitya by paying rent to the bank on Panitya Lndreform's account;

Considering that the witness had been heard under the oath of R. Chief of the Agrarian Inspection of West Nusa Tenggara who explained according to the materials in his office file, among others, derivatives of the Testament derivative (the first derivative made by Punggawa Tjakranegara) were in fact the agricultural land in this case indeed, it is proven that the existence of "Dowe Tengan" is true (the rights with unregistered heirs), and the position of Defendant I is only as administrator of the inheritance, the proceeds for the benefit of all members of the inheritance. And it is also clear that the report made based on Article 3 of Law Number 56 Prp / 1960 has been wrongly made by Defendant I, that all land should be registered as land that is merely controlled (due to its duties), and is not registered as its own land, and therefore research by Panitya is based on material that is not correct, then the decision is also not true;

Actually Panitya Landreform Level II can review the decision to get improvements;

Furthermore, explained by the witness, that the inherited lands which came into effect at the time of the enactment of Law Number 56 Prp in 1960, should be immediately resolved to be divided first, and determined which entitled heirs to the maximum and new limits of the excess land controlled by the State;

Considering the first claim regarding the distribution of inheritance in the land of Tjidra has been submitted before the LoGA, namely on January 8, 1958 (List of Case No. 10/1958 / PN / Pdt). the hearing on May 22, 1958, the claim was revoked for repairs. Then, on November 25, 1958, a new lawsuit was filed (Registered Number: 422/1958 / PN / Pdt). When it was examined before the trial on August 25, 1951 it turned out that the lawsuit was not perfect (not all members of the inheritance were revealed) given a stipulation, it was stated that the lawsuit was not accepted, by providing an opportunity also to make and file a new claim;

Then on January 29, 1962 also submitted a corrected claim (Registered Number 92/1962/PN/Pdt), but after the inspection, one of the Plaintiffs died and three people withdrew, did not participate in suing, with that then the lawsuit was not perfect, then on September 21, 1963 the lawsuit was filed and declared "not accepted" and on September 21, 1963 also by the Plaintiff's Attorney (Ide Wayan Windia) filing a lawsuit was recently registered Number 474/1963 / PN / Pdt; 
Considering that while waiting for the settlement of the case, the Agrarian Inspection has taken policy steps, has redistributed 213 hectares of dry land, such as the statement of witness R. Rank, therefore there is still a large amount left to divide in the maximum limit, because the land is entirely (rice fields / the garden of origin consists of $700 \mathrm{Ha}$;

Considering that witness Ide Bagus Tantre typist at the Tjakranegara District Office swore to explain and show the archive file of the Head of the District Office (formerly Punggawa) in the statement letter No. 4 of 1955, on June 21, 1955 in relation to the making of the deed. Reduce the original inheritance letter referred to in this case which is sewn in the deed file;

Considering that the contents of the Testament derivative are the same as the derived letters submitted by the witness R Rank of Head of Agrarian Inspection;

Considering that the selected land became their portion, the information of the Plaintiff and Defendant's power was made as far as the Head of the Bureau of Taxes on Agricultural Products and Head of Agrarian Inspection in Mataram with no doubt about the land taken as part of it including one from the land the land distributed, even in their choice adjusted to the relationship with the cultivators of those lands;

Considering whereas based on these considerations, it is evident that the land of Tjidra is not the private property of the Defendant I, and that the peace between the Plaintiffs and the Defendants is not against the law, therefore it is appropriate to be granted and strengthened before the trial;

In view of the Civil Procedure Code stated in Article 154 of the RBG

Judge:

Strengthening peace between the Plaintiff and the Defendant.

From the dispute, it can be seen that in fact this case concerns the land reform program. It appears that at a glance the Plaintiffs and Defendants are individuals who need their land (Tjidra land) back through peace. However, because the land of Tjidra is relatively very broad, namely $213 \mathrm{Ha}$, it is necessary to present Panitya Landreform so that court decisions do not conflict with applicable laws and regulations (Law number 5 of 1960, and Law 56 Prp of 1960).

In addition, it can be clearly seen that the implementation of the Land Reform program is a program based on the philosophy of life of the Pancasila nation and state, which limits the expulsion of land to an individual. Before Pancasila became the basis for national life, the structure of land ownership and control was very lame. Some individuals control land that is very excessive; this happened during the Dutch East Indies era following the capitalist individualist philosophy adopted by the Dutch colonialists.

\subsection{Reasons for Existence ("Raison D'etre") In the Replacement of Regulations on Registration of Land Rights}

The existence of the replacement of land registration regulations basically depends largely on the direction of the State constitution which is found on the principles specified in the 1945 Constitution. Indeed, the principle is very abstract but can be understood in its implementation in the legislation on land rights and land use policies.

In establishing land rights along with land use policies carried out by the government, it is very different from the reality before PP 24 of 1997 was applied, because when this government regulation was implemented there was found the application of new principles (efficiency-justice) in the 1945 Constitution. on land, especially for the interests of rulers who issue land rights that are not based on legislation, namely Management Rights (HPL is contrary to the sound of Article 33 Paragraph 4 of the 1945 Constitution). HPL is indeed for the benefit of the government and employers to jointly control the relatively wide area of strategic land, such as in Mandalika Tourism Resort. The West Nusa Tenggara provincial government has designated the Kute beach area in Central Lombok to be a tourist area. An area of 1,250 hectares is designated as a Management Right in collaboration with PT Rajawali to build a LTDC company. In this regard, PT Rajawali is granted Building Use Rights directly on State land (Novotel Hotels), meaning not on land under management rights. HPL LTDC removes individual property rights; of course some holders of property rights claim land rights. The Supreme Court found that Sulame and the Mamiq Kalsum family were successful. This fact raises the awareness of individuals that the lawsuit against LTDC is currently in the process of being appealed.

Determination of HPL as land rights based on the authority of the State developed a pattern of registration of land rights known in the Minister of Agrarian Regulation / Head of the National Land Agency Number 9 of 1999, concerning Procedures for Granting and Cancellation of State Rights and Management Rights. In line 
with that, the authority and ownership of HPL was handed over to the Ministry of State-Owned Enterprises by the Provincial and Regency Governments. This fact gave birth to the idea of the principle of equalityjustice incorporated into Article 33 (Paragraph 4) of the 1945 Constitution of the Republic of Indonesia in the IV Amendment of the 1945 Constitution along with other economic principles such as Family, Togetherness, Sustainability and Environmental Sustainability.

In line with this, cases and legal problems were found in the HPL ITDC area (formerly LTDC). This land has not been filed by individuals who own it, but there have been legal decisions that underlie ownership of these rights. The legal verdict was in the form of a Supreme Court Decision Number 1157 K / Pdt / 1992, which was won by the Respondents, previously Comparable and the Defendant named Mr. Minase and Lalu Bayak who were opposed was Amaq Sawi as the Cassation Appellant, the Plaintiff and Comparator.

The object of the dispute is within the HPL LTDC area (facing the Mandalika Kute Lombok Regional monument); Proposal of the Plaintiff (Amaq Sawi):

That the original claim in 1970 with the approval of the Central Lombok District Government of the Original Plaintiff was to open the forest to be used as agricultural / plantation land in the Kute village area of Pujut District, Central Lombok Regency is now a Tourism Area;

That by the land acquisition committee namely the Landreform Committee at that time on the land that the Original Plaintiff was not, after being measured the area was 1,240 Ha, and in 1973 the Government through the Central Lombok District Landform Committee, issued a Land Permit for and on behalf of the Original Plaintiff dated 15 November 1973, Number: 153 / KT / 1973;

That after the Original Plaintiff maintained / worked on the land with coconut cultivation and so on, and around 1975 Mr. Minase (Original Defendant I) who at that time Kaluang Penjalu Hamlet took the original Plaintiff's land on the grounds that it would be taken by the Government and would be made a location development, and if there is fear / fear and there are grandiose promises, finally the land of the Original Plaintiff simply gives up;

That then without the knowledge of the Original Plaintiff, which is around 1988, the original Plaintiff's land was in the hands of the Original Defendant II Then Bayak, where the Original Defendant II was an individual not the Government, and recognition of the Original Defendant II could be purchased from the person the Original Plaintiff did not know;

Whereas now on the land the dispute is by the Original Defendant II having established four lodgings / lodgings which are certainly without the permission of the Original Plaintiff;

That the Original Plaintiff has repeatedly contacted the Original Defendants to retain for fabricated reasons;

That based on the description above, the Original Plaintiff requested the Praya District Court to provide a verdict, as follows:

1. To grant the Plaintiff's claim in its entirety;

2. To declare that the dispossessed garden land belongs to the Plaintiff Amaq Sawi;

3. Declares that the Plaintiffs have no right to control and work on the dispute land;

4. Declare null and void of all transactions that apply to disputed garden land;

5. Punish the defendants or anyone who has the right to surrender the dispute to the Plaintiff in good condition and empty garden land, if necessary with the assistance of the Police;

6. Sentencing the Defendants to pay the cost of the cases arising in this case;

7. Or the District Court gives another decision that is deemed fair.

That it turned out that the Plaintiff's claim had been completely rejected by the Praya District Court in the decision dated May 8, 1991, Number: 50/Pdt.G/1990 / PN. Pre. This decision at the appeal level was confirmed by the Mataram High Court in its decision on September 10, 1991, Number: 157/Pdt/1991/PT.NTB;

After going through the legal process, the cassation request which was previously the Plaintiff, the Comparator received an appeal request with the decision, that Judex facti had been wrong in applying the law, namely:

1. Whereas the consideration of evidence from the Cassation Applicant / Originator in the form of a Land Permit dated 15 November 1973, Number: 153 / KT / 1973 (Product P.1), is contrary to PMDN Number 6 of 1972, according to him / consideration the judge that the Land Work Permit is incorrectly issued by the Land Reform Committee, the judge should consider CHAPTER VIII Article 16 of the Domestic 
Investment (Number 6 of 1962), which reads: "With the enactment of this regulation all land rights are carried out based on Domestic Number 11967 still applies;

So that if PMDN Number 1 Year 1967 is used as material for Judges' consideration in deciding this case, it is clear that the proof of product P.1 is a Land Permit Permit dated 15 November 1973, Number: 153 / KT / 1973 can be justified;

2. Whereas the results of the local inspection which confirmed that the boundaries of the disputed land no longer existed, namely the real form of fences from plants had not been found anymore, indicating that the object of the dispute was unclear;

The application of the law in the status quo state of the object of dispute such as a long-standing situation cannot be used as a basis for consideration, according to the present situation; it does not mean that the object of the dispute is unclear and vague;

Weigh:

Regarding objections ad 1.

That this objection cannot be justified, because this is essentially about the results of proof that are appreciative of a reality, which cannot be considered in the examination at the cassation level, because the examination at the cassation level is only concerned with not being implemented or there is an error in the implementation of the law ;

Regarding Objection ad 2.

That this objection cannot be justified, because judex faction does not wrongly apply the law;

Considering, that based on what is considered above, besides from the fact that it turns out that thejudex factual decision in this case is contrary to the law and / or law, the appeal request submitted by the Amaq Sawi Cassation Applicant must be rejected.

Judge:

Refuse the appeal from Amaq Sawi's Cassation Appellant.

It is easy to know that this case occurred in the period before Government Regulation Number 24 of 1997, so that during the regulation on registration of land rights Number 10 of 1961. Indeed, in this appeal the decision was made to show the authority to determine land rights as different from land use permits. Establishing land use permits as agricultural or plantation land is not a Land Reform Committee but rather a Regency Regional Government based on Domestic Investment (PMDN) regulations for tourism areas (in fact when it is used as lodging). Besides that, it was interesting to say that Lalu Bayak and his family did not have the awareness to register rights to the land office even though the area where the land was located had begun to become a tourist visiting area on Lombok Island. It was only then based on Regional Regulation No. 9 of 1989 that Regional Regulations on Tourism stipulated Kute Lombok Beach to be a tourist visit area, together with the Provincial Government stipulating 1,250 Ha of Kute Beach area to become Government Management Right, so that it included Then Bayak's land area into Rights Government Management.

As a result, the rights to Lalu Bayak land must be handed over or released to the government (which holds the Management Right). Surely the Lalu Bayak heirs (Then Bayak died 1995) did not want to surrender their land to the government or in this case LTDC (ITDC). One of the Putra Bayak Men named: Lalu Erwin Martakota, SH was allegedly / charged with carrying out land control with the Indonesian Tourism Development Corporation (ITDC) Land Management Rights. In Case Number: 7 / Pid.C / 2015 / PN. Pra, the ITDC complained to Lalu Erwin Martakota, SH based on the rights held by HPL certificate Number 28 Kute Village, Pujut District, Central Lombok Regency, covering an area of 18,400 square meters, with the following limits: North: Amaq Tiwi's land; Selatan: Jalan Raya Kuta Grupuk; Timur: Iskandar Muda Land; West: Land I Putu Tusta.

Considering, that on the testimony of the witnesses, proof of the letter, testimony of the Defendant in court, and instructions obtained from the conformity of the statements of witnesses and defendants, the Praya District Court obtained the facts as follows:

a. That it was true that the Defendant had controlled an area of around 18,400 m2 located in Ketapang Hamlet, Kute Village, Pujut District, Central Lombok Regency by constructing a residential building; 
b. That was true based on testimony from witness Deni Reto Wardani, witness Mariane, and witness Sajargare that the land belonged to the ITDC based on the Management Rights Certificate, Number 28, Kute Village, Pujut District, Central Lombok Regency;

c. That it is true that based on witness Tahum alias Amaq Kanem, witness Mendang, witness Munaje, and witness Kasijan and the testimony of the Defendant that the land held by the Defendant was the land of the Defendant, and the Defendant obtained from his parents a grant named Lalu Bayak (proof T.1);

d. That it was true that the Defendant had occupied the land for a long time by building a house of residence, and before the Defendant who occupied the land was the parents of the Defendant named Lalu Bayak with his wife and children (including the Defendant);

e. That is true that the ITDC has never mastered, utilized or made buildings on land that has been controlled by the Defendant;

Considering the facts revealed at the trial, can it be said that the Defendant has been guilty of a criminal act as charged to him;

Considering that based on legal facts at the trial of witness Tahum alias Amaq Kanem, witness Mendang, witness Munaje, and witness Kasijan and the Defendant's statement that the Defendant was indeed in control by building a place of residence on the land because the Defendant felt that the land was his property obtained from the gift / grant from the parents of the Defendant named Lalu Bayak in 1989, and according to the confession of the Defendant his parents never sold the land to ITDC or to anyone. Whereas information from witness Deni Reto Wardani, witness Mariane, and witness Sajargare that the ITDC had purchased the land from the Defendant's parents and had been certified with Management Rights Number 28 of Kute Village, Pujut District, Central Lombok Regency;

Considering whereas based on the foregoing consideration that the Defendant's actions control the land of an area of 18,400 m2 located in Ketapang Hamlet, Kute Village, Pujut District, Central Lombok Regency by constructing the residence is not a criminal offense because between ITDC as victims and defendants together acknowledging the right to ownership of the land, which dispute has been included in the principal authority of the Civil Law examination material and is not subject to the Criminal Law Examination, so that the Defendant must be released from all legal claims (onslag van recht vervoging).

The trial was actually a result of the existence of a registration system for land rights aimed at the interests of ITDC companies. The authorities became entrepreneurs, so that the land tenure to be managed by the Government was carried out by "seizing the rights" of the people. The government through the development program increases Regional Original Revenue by utilizing various natural resources in the region. This fact occurs throughout Indonesia emphasizing that useful resources generate the greatest possible profit for the prosperity or welfare of the people. In fact this is the essence of capitalism which is also at the same time communism (control of resources by the State).

This was more evident when on May 1, 2018, the Lalu Bayak family including Lalu Erwin Martakota (son of the deceased Lalu Bayak) were expelled from their land by law enforcement officials as if the land had been executed using the Civil Service Police and Central Lombok Resort Police.

What is taken from this case? It is easy to understand, that this nation cannot avoid the pattern of life of liberalism or capitalism, as well as socialism. Meanwhile, Pancasila must be the essence of life and people's lives. Pancasila is the foundation of the nation's philosophy. The essence of Pancasila philosophy contains the noble values that have been believed by the Indonesian people. At present the Pancasila is being combined with the principle that was born in the Capitalist State, namely the principle of Efficiency-Justice listed in Article 33 (Paragraph 4) of the 1945 Constitution. What is the response that needs attention? Will the principle of Efficiency-Just be allowed in the course of the life of the nation so that the economy of the people is in debt? How is the legal construction (Functional Requirements) prepared to respond to structural conditions as a result of the application of the Fair-Efficiency principle?

\section{Conclusion}

From the description above is an analysis and discussion of the problems under study, conclusions can be drawn, that the Right to Mastery over Land held by the Government is limited if as a ruler enters the economic sector. More details can be found:

Registration of land rights cannot be separated from the ruler's politics of land use. In the implementation of PP 10 in 1961 the government seized the land rights of the people (who owned excess land), then 
redistributed the people who needed it as agricultural land (in addition, the land of the redistribution program was controlled by the government as an asset for public interest; in line with It was found a different political attitude at the time of the implementation of PP 24 of 1997, namely: by laying the foundations of new economies and in fact contrary to the Pancasila Philosophy, namely the principle of Efficiency-Equity, although this Principle was only known in 2002 (August 10, 2002) but in fact it was implemented at the beginning of Repelita I by enacting Law No. 1 of 1967 (Foreign Investment), so that the maximum achievement for people's prosperity which was relatively difficult to achieve (PP 10 of 1961) turned to increasing government original income (PAD).

Based on these conclusions, this study proposes suggestions or recommendations as follows: the establishment of regulations relating to registration of land rights should be based on principles that are consistent with the foundation of the philosophy of life of the nation and the State of Pancasila; Substitution of PP 10 of 1961 with PP 24 of 1997; not registering Management Rights, those that have already been immediately canceled because they conflict with Article 33 (Paragraph 5) of the 1945 Constitution; Redefining the legal substance of registration of land rights that is in harmony with the ideological foundation and or philosophy of life of the nation, Pancasila.

\section{References}

[1] Achmad Chomzah, Ali, Hukum Agraria jilid 2, Jakarta: Prestasi Pustaka, 2004.

[2] Ali, Achmad, Menguak Teori Hukum (Legal Theory) dan Teori Peradilan

[3] (Judicial prudence) Termasuk Interpretasi Undang-Undang (Legisprudence), (Jakarta, Kencana Prenada Media Grup, 2009.

[4] Banakar, Reza, Normativity in Legal Sociology Methodological Reflections on Law and Regulation in Late Modernity, Springer International Publishing, 2015.

[5] Barkun, Michael., Law and the Social System, Lieber-Atherton, Incorporated, New York, 1972.

[6] Bierdtedt, Robert., The Social Order, McGraw-Hill Book \& co, New York, 1974.

[7] Bohannan, P., Law and Warfare: Studies in the Anthropology of Conflict, University of Texas Press, Austin, 1967.

[8] Bentham, Jeremy, Teori Perundang Undangan, Prinsip Prinsip Legislasi Hukum Perdata dan Hukum Pidana, terjemahan dari The Theory of Legislation, ( Bandung, Penerbit Nusa Media, 2006.

[9] Cohen, Morris R., Law and the Social Order: essays in legal philosophy, Archon Books, 1967.

[10] Craib, Ian., Modem Social Theory: from Parsons to Habemtan, (edisi - Indonesia), Rajawali, Jakarta, 1984

[11] Duncan Kennedy, “The Structure of Blackstone's Comentaries”, Bufallo Law Review, 28, 1979.

[12] Dror, Yehezkel., "Law and Social Change", dalam Grossman, Joel B., dan Grossman Mary H., Law and Change in Modem America, Pacific Palisades, Cal.: Goodyear Publishing, Inc, 1971.

[13] Hadikusuma, Hilman, Hukum Waris Adat, Bandung: Citra Aditya Bakti, 1999.

[14] Harsono, Boedi, "Peraturan Pemerintah Nomor 24 Tahun 1997 Tentang Pendaftaran Tanah (lsi dan Penjelasannya)," Makalah disampaikan dalam Seminar Nasional di Jakarta kerjasama FH Trisakti dengan BPN, 14 Agustus 1997.

[15] Harto Juwono, Antara Bezitsrecht dan Eigendomrecht: Kajian Tentang Hak Atas Tanah Oleh Penduduk, dalam Jurnal Hukum dan Peradilan, Volume 2 Nomor 1 Maret 2013 ISSN: 2303-3274.

[16] H.T. Collenbrander, Koloniale Geschiedenis, derde deel: Nederlandsch Oost Indie sedert 1816 ('s Gravenhage, 1926, Martinus Nijhoff), dalam Sediono M.P. Tjodronegoro dan Gunawan Wiradi, Dua Abad Penguasaan Tanah: Pola Penguasaan Tanah Pertanian di Jawa dari masa ke masa Yayasan Obor, Jakarta, 2008.

[17] Huijbers, Theo, Filsafat Hukum Dalam Lintasan Sejarah, (Yogyakarta, Pustaka Filsafat, Kanisius, 1982.

[18] Jaap Zevenbergen, System of Land Registration: Aspects and Effects, Delft: Geodesy, 2002.

[19] Lubis, Yamin dan Rahim Lubis, Hukum Pendaftaran Tanah, Mandar Maju, 2012.

[20] Mangabeira Unger, Roberto, Law in Modern Society, Free Press, New York, 1976.

[21] Nazir, Muhammad, Heri Priyatmoko, Muh Arif S, "Dari Dirjen Agraria Menuju Kementerian Agraria: Perjalanan Sejarah Kelembagaan Agraria, 1948-1965”, Penelitian Sistematis 2014, PPPMSTPN, 2014. 
[22] Noer Fauzi Rachman, Land Reform dari Masa ke Masa. Perjalanan Kebijakan Pertanahan 1945 2009, Yogyakarta: Tanah Air Beta, 2011.

[23] Pound, Roscoe, Jusriprudence, Volume I, New Jersey: The Lawbook Exhange, 2000

[24] Peter Mahmud Marzuki, Penelitian Hukum, 2nd edition of the first print. Kencana Prenada Media Group, Jakarta, 2006.

[25] Roberto Mangabeira Unger, Law in Modern Society, (Free Press, New York, 1976. 